Original Research

\title{
Change of Consciousness Through Oxygen Supply in Head Injury
}

\section{Khoiriyah Khoiriyah'1, Hendi Ardiananto²}

${ }^{1}$ University of Muhamadiyah Semarang

2 Dr. Kariadi Hospital Semarang

\section{Article Info}

Article History:
Accepted September 30th,
2019

Key words:

Consciousness level; Head injury; Simple Mask; Head Elevation

\section{INTRODUCTION}

Head injury is a series of pathophysiologic events that occur after head trauma which involve severe head component, ranging from the scalp, bones, and brain tissue or a combination. Head injury is one of the leading causes of death and disability in the productive age group and most of it occurs
Abstract

Head injury is one of the main causes of death and disability in the productive age group and most occur due to traffic accidents. Patients with a head injury can experience permanent damage to brain tissue or secondary injuries such as brain ischemia due to hypoxia, hypercapnia, hyperglycemia or electrolyte imbalance, even respiratory failure and heart failure. The head injury patients are initially examined using a standardized scoring system to assess the consciousness level of patients with impaired consciousness, namely the Glasgow coma scale (GCS). One of the possible treatments for decreasing intracranial pressure (ICP) and cerebral perfusion managements to position the patients with a head elevation of $15^{\circ}-30^{\circ}$. This treatment aimed to increase venous drainage from the head and to reduce systemic blood pressure that may be compromised by cerebral perfusion pressure. This study aimed to determine the effect of giving oxygen through a simple mask and the $30^{\circ}$ head elevation position to the changes of the consciousness level for the patients witha head injury in the emergency department at Dr. Kariadi Hospital, Semarang. This study was quasi-experimental research without control with pre-test and post-test one-group design with used a sample of 23 respondents. The instrument used an observation sheet containing the GCS examination results and analyzed using the Wilcoxon test. Based on the results of the bivariate analysis using the Wilcoxon correlation test, a p-value of $0,000<0,05$ was obtained so it could be concluded that the $\mathrm{HO}$ is accepted. Therefore, giving oxygen through simple masks and patient positioning with $30^{\circ}$ head elevation affect the consciousness level of head injury patients at Dr. Kariadi Hospital, Semarang.

Corresponding author:

Khoiriyah

khoiriyah@unimus.ac.id

South East Asia Nursing Research, Vol 1 No 2, September 2019

ISSN:2685-032X

DOI: https://doi.org/10.26714/seanr.1.2.2019.76-82

due to traffic accidents. ${ }^{1}$ Poorly treated head injury patients tend to have a secondary brain injury in addition to primary brain injury which will result in brain ischemia. ${ }^{2}$

Patients with a head injury can experience permanent damage to brain tissue or secondary injuries such as brain ischemia due to hypoxia, hypercapnia, hyperglycemia 
or electrolyte imbalance, or even respiratory failure and heart failure. ${ }^{3}$ As a result of trauma, the patient experiences physical and psychological changes. Severe head injury often resulting in secondary brain injury, cerebral edema, airway obstruction, increased intracranial pressure, vasopasm, hydrocephalus, metabolic disorders, infections, and seizures. ${ }^{4}$ Patients who experience decreased consciousness generally experience airway disorders, respiratory problems and circulatory disorders. ${ }^{5}$

The brain is a vital organ for all activities and functions of the body, because there are various control centers such as physical, intellectual, emotional, social, and skill control in it. Eventhough the brain is in a closed space and protected by strong bones, it can also experience damage. One of the causes is a head injury that can cause damage to brain structure that leads to disruption of brain function.

Normally, the brain requires $30-40 \%$ oxygen of the total body's oxygen needs. Since the brain does not have oxygen reserves, the incoming oxygen supply will be used up. To maintain adequate brain oxygenation, a balance is needed between oxygen supply and brain oxygen demand. Brain oxygen balance is affected by cerebral blood flow, which ranges from $15-20 \%$ of cardiac output. Good management of head injury must begin from the scene of injury, during patient transportation, at the emergency department until definitive therapy is performed. Correct and proper management will affect the patient outcomes. The initial examination performed on patients with head injury using the Glasgow coma scale (GCS) which is a standardized assessment system used to assess the level of awareness in patients with impaired consciousness. It includes the numerical calculation of cognitive, behavioral, and neurological functions. The results can be used to measure the level of awareness of head trauma patients, which is one of the components used as a reference for treatment and the basis for general clinical decision making for patients. ${ }^{6}$

Based on the results of the Riset Kesehatan Dasar (RISKESDAS) in 2013, from $1,027,758$ people of all ages, there were 84,774 injured respondents and 942,984 people not injured. The national injury prevalence is $8.2 \%$ and the prevalence of head injury in Central Java is $8.3 \%$. The highest injury prevalence based on the characteristics of respondents is in the age group of $15-24$ years (11.7\%), and in men $(10.1 \%)^{8}$

Based on the data from RSUP Dr. Kariadi Semarang in 2017, there were 189 patients who suffered a head injury. The data from the General Hospital Dr. Kariadi Semarang showed that there were 168 patients with a head injury from 612 case of traffic accidents recorded from January to August 2018. Every time an accident occurs and the victim experiences a collision in the head, especially if it causes the patient to become unconscious, must be considered a serious and dangerous accident with the suspicion of brain concussion. Likewise, every victim who is fainted and thought to have suffered a head injury must be treated carefully. ${ }^{3}$

In the study conducted by Febriyanti, et al (2017), which used paired t test $\mathrm{SaO} 2$ before and after the first 10 minutes, pvalue $=0.000<\alpha 0.05$ were obtained in the first 10 minutes and the second 10 minutes tests. The tests between the second 10 minutes and the third 10 results in $p$-values $=0.005<\alpha 0.05$ and repeated ANOVA tests. These results showed that there is an influence of prong nasal oxygenation therapy on the changes in oxygen saturation of head injury patients in the Emergency Department of Prof. RSUP Dr. R. D. Kandou Manado.

A preliminary study was carried out on 28 September2018 at Dr. Kariadi Semarang within the period of January - August 2018.There were 150 head injury patients and head injury were the most common 
diagnosed case in the surgery. Head injury will provide a more complex disorder when compared to the trauma on other body organs. This is due to the anatomic and physiological structure of the skull contents, which are brain fluid, brain membranes, nerve tissue, blood vessels and bones, having the consistency of liquid, soft solid and dense solid. Patients with head injury require early diagnosis so that therapeutic measures can be taken immediately to produce a precise, accurate and systematic prognosis. Because of the high number of head injury incidents, the writeris interested in researching about changes in signs of increased intracranial with the title "The Effect of Oxygen Administration Through Simple Masks and 30 Head Position to the Changes in Awareness Levels of the Patients with Mild and Moderate Head Injury.

\section{METHODS}

This study uses the quantitative research methods with quasi-experiment research. The research design used was pre-test and post-test one group design. The subjects were head injury patients in the ER of RSUP Dr. Kariadi Semarang with a total sample of 23 respondents using purposive sampling. Data collection was done by observation and using the Consciousness Level. It is used to assess the patient's level of consciousness and neurological status. Data analysis was performed using univariate analysis, normality test and bivariate analysis (NonParametric Test i.e.Willcoxon Test). The inclusion criteria in this sample were all head injury patients recorded in the medical record, head injury patients who had been examined for consciousness level, patients with injury classification. Severe head injury, moderate head injury and mild head injury. The research process includes selecting head injury patients used Glasgow Coma Scale (GCS) score results by looking at inclusion and exclusion criteria, taking GCS assessment data for subjects that have the inclusion criteria, providing oxygen through a simple mask for 6 hours and head elevation position $30^{\circ}$ for 2 hours, and reevaluating the subjects GCS assessment results after the treatment.

\section{RESULTS}

The result of this study shows that the majority of E values (eye) with a score of 3 are 17 people $(73.9 \%), \mathrm{V}$ values (verbal) with a score of 5 are 8 people (34.8\%), M scores (motoric) with a score of 5 are 11 people (47.8\%). Based on Table 1, most of the $E$ (eye) scores with a score of 4 were 14 people $(60.9 \%), \mathrm{V}$ (verbal) with a score of 5 were 13 people (56.5\%), M (motorik) with a score of 6 a total of 16 people (69.6\%).

Tabel 1

GCS Assesment Distribution Before and after Intrevention

\begin{tabular}{cccc}
\hline Indicator & Score & f & \% \\
\hline Before intervention & & & \\
Eye & 1 & 1 & 4,3 \\
& 2 & 4 & 17,4 \\
Verbal & 3 & 17 & 73,9 \\
& 4 & 1 & 4,3 \\
& 1 & 1 & 4,3 \\
Motorik & 2 & 6 & 26,1 \\
& 3 & 1 & 4,3 \\
& 4 & 7 & 30,4 \\
& 5 & 8 & 34,8 \\
After intervention & 2 & 1 & 4,3 \\
Eye & 4 & 1 & 4,3 \\
& 5 & 11 & 47,8 \\
& 6 & 10 & 43,5 \\
\hline Verbal & 2 & & \\
& 3 & 8 & 4,3 \\
& 4 & 14 & 60,9 \\
& 2 & 1 & 4,3 \\
& 3 & 4 & 17,4 \\
Motorik & 4 & 5 & 21,7 \\
& 5 & 13 & 56,5 \\
& 3 & 1 & 4,3 \\
& 5 & 6 & 26,1 \\
& 6 & 16 & 69,6 \\
\hline & & &
\end{tabular}

Based on the analysis using the Wilcoxon correlation test (table 2), a p-value of 0,000 $<0.05$ was obtained so that it can be concluded that the $\mathrm{H}_{0}$ was accepted. This means that there is a significant difference in the level of awareness between before and after administering oxygen through a simple mask and $30^{\circ}$ head elevation 
position in the head injury patient in the emergency room (ER) of RSUP Dr. Kariadi Semarang.

Table 2

TheAwareness Level Before and After Oxygen Administration Through Simple Mask and 30o Head Elevation Position of Head Injury Patient in the ER of RSUP Dr. Kariadi Semarang ( $n=23)$

\begin{tabular}{lccc}
\hline Indicators & $\begin{array}{c}\text { Pre } \\
\text { Intervention }\end{array}$ & $\begin{array}{c}\text { Post } \\
\text { Intervention }\end{array}$ & $\mathrm{p}$ \\
\hline GCS & $11.70(2.54)$ & $13.57(1.92)$ & \\
$\begin{array}{l}\text { Levels, } \\
\text { Mean(SD) }\end{array}$ & & & $0,000^{*}$ \\
Min-Max & $6-14$ & $9-15$ & \\
\hline
\end{tabular}

*Wilcoxon test

\section{DISCUSSION}

Based on the results of the study, we found the average size of the GCS score before being given oxygen through a simple mask and $30^{\circ}$ head elevation position was 11.70 , while the average size of the GCS score after being given oxygen through a simple mask and $30^{\circ}$ head elevation position was 13,57 . From the test results using the Wilcoxon Test, the $p$ value of $0,000<0.05$ was obtained so that it can be concluded that $\mathrm{H}_{0}$ is accepted. This means that there is an influence of oxygen delivery through simple masks and $30^{\circ}$ head elevation position to changes in the level of consciousness in head injury patients in the ER of Dr Kariadi Hospital Semarang.

Head injury is damage to the head that is neither congenital nor degenerative, but is caused by an attack or physical impact from the out side which can reduce or change in consciousness and causing damage to cognitive abilities and physical function. A head injury can occur as a result of collisions on the head in 3 types of conditions, which are a stationary head being hit by a moving object, a moving head hit by a stationary object, and a head that cannot move because it rests on another object hit by a moving object. Based on the severity of head injury, it can be classified into mild head injury(GCS 13-15, amnesia less than 30 minutes), moderate head injury (GCS 9-12, loss of consciousness 30 minutes - 24 hours), and severe head injury (GCS 3-8, a decrease in consciousness of more than 24 hours to days). ${ }^{10}$

An increase in ICP is an emergency that must be dealt with immediately. When the pressure rises, the brain substance is suppressed. Secondary phenomena are caused by circulatory disorders and edema can cause death. Intracranial enhancement occurs when the value of intracranial pressure is more than $15 \mathrm{mmHg}$ which is characterized by clinical syndromes indicated by an increase in blood pressure, decreased pulse, changes in respiration and changes in pupils. The impact of increased intracranial pressure on cerebral circulation will cause an increase in intracranial pressure and decreases cerebral blood flow resulting in ischemia. 35 minutes of ischemia will cause irreversible brain damage so that it stimulates the vasomotor center and systemic pressure increases to maintain the blood flow such that the pulse slows, breathing becomes irregular and blood pressureincreases. ${ }^{12}$

Head up sleeping position allows the chest cavity to develop widely and increase the lung complaints. This condition will cause oxygen intake (oxygenation) to improve and the respiration process returns to normal. Positioning the patient with a slight head elevationof $30^{\circ}$ to increase venous drainage from the head and head elevation can cause a decrease in systemic blood pressure which may be compromised by cerebral perfusion pressure. Head up sleeping position arrangement allows the chest cavity to expand widely and increase lung complaints. This condition will cause oxygen intake (oxygenation) to improve so that the respiration process returns to normal. ${ }^{39}$

This is related to low GCS which is a predictor of death in head injury patients. Measuring GCS is an important intervention that must bed one by nurses in the ER room when providing nursing care to patients 
with a head injury. In severe head injury, GCS values tend to be quickly decreased due to the compensation mechanism of the human body when the reisan increase in intra-cranial pressure. Head injury patients require adequate oxygen supply to meet the brain's metabolic needs. Oxygen saturation observation is carried out to prevent and recognize the risk of tissue hypoxia. Tissue hypoxia will cause a risk of secondary trauma to brain tissue which will result in the death of the patient. Peripheral oxygen saturation below $90 \%$ indicates hypoxemia condition. ${ }^{14}$

Low oxygen saturation significantly increases the risk of death, patients with the saturation $<80 \%$ have a threefold increased risk of death. Hypoxia is a predictor of poor outcomes in patients with a moderate and severe head injury as a result of the additional risk of secondary brain injury experienced by the patient.As much as 27$55 \%$ recorded hypoxia can originate from the scene, in the ambulance / when transportation, or upon arrival at the emergency department.

The level of awareness of head injury patients assessed by the GCS score is a measure of the clinical condition of the head injury patients examined when the patient arrives at ER. The level of awareness evaluated with GCS score has a strong influence on the life chances and recovery of the head injury patients. The GCS score is one of the mandatory examinations in patients with head injury at the time of hospital admission. A low initial GCS score indicates a severe disturbance in the brain function associated with the risk of the death of the patient. Brain disorders that continue with brain tissue death are important, because the nature of brain tissue tends to be irreversible in the event of death. ${ }^{40}$

Disorders and damages that occur in the brain will disrupt the work of the body vital systems, such as breathing and cardiovascular, systems, and result in the threat of death. Attention to the patient's family must also be given to provide emotional and spiritual support. The treatment for the head injury patients with low GCS will get a priority, this is indicated by the use of the level of awareness as a component in triage that serves to prioritize patient management. Patients with low awareness will fall into the first priority category. Priority is done to prevent worse complications and even death in patients. ${ }^{39}$

The main focus of head injury patient's management is to prevent secondary brain injury. Providing oxygenation and maintaining good and adequate blood pressure to fulfill brain perfusion is the most important factor, especially to prevent and limit the occurrence of secondary brain injury which will ultimately improve the patient's end result. This is in accordance with Patria (2012) that head injury patients should be given oxygen therapy using masks or reservoir masks with oxygen concentrations of $40-80 \% .^{16}$

Hypoxia is a condition inadequate tissue oxygenation at the tissue level which occurs due to deficiency of oxygen delivery or the use of dicellular oxygen. Oxygenation is the most basic human needs. The existence of oxygen is a component of gas and a vital element in the metabolic process and to maintain the survival of all body cells. Maslow's Hierarchy theory is a theory that nurses can use to understand the relationship between basic human needs when providing care. Physiological needs are important for survival, one of which is oxygenation needs. Christopher etal. (2012) concluded that the oxygenation of brain tissue is closely related to several parameters of patient outcome and prognosis. The application of intervention therapy to maintain oxygenation of brain tissue above a certain threshold can improve mortality and neurological outcomes in the head injury patients. Head elevation based on physiological response is a change in position to increase blood flow to the brain and prevent an increase of ICP. 
Some clinic nurses perform bedrest with a head elevation not more than $30^{\circ}$, rationally preventing the increased risk of decreasing cerebral perfusion pressure and further worsening cerebral ischemia if vasospasm is present. ${ }^{43}$

This is in line with the research conducted by Lesko (2012) which states that the total GCS score is a good predictor of death for head injury patients. GCS is related to a disturbance in brain structure or tissue. According to Maas, Engel, and Lingsma (2011), there are several studies that showed an association between lower scores on GCS and worse outcomes. In patients with severe head injury, the motor component of GCS has the greatest predictive value because eye and verbal responses are generally absent in patients. The GCS score in this study uses an interval scale, with a middle value of 10 , a minimum value of 6 and a maximum value of 15 . The results of this study are consistent with research conducted by Emery, Durward and Fieldman (2003) who found that the head position up to $15^{\circ}$ significantly reduced the intracranial increase which is due to the effects of jugular venous system pressure and there was a decrease in heart rate from $0.76 \%$ to $5.6 \%$. Another similar research was conducted by Setterval, Souza and Silva (2011) where GCS scores were assessed three times during 72 hours after injury. The findings of this study showed that GCS has a relationship with the outcome of head injury patients. Research conducted by Duward et al. and Lee et al. also states that a head up position of 15 to 30 head was progressively reducing arterial pressure and decreasing CVP ( $\mathrm{p}<0.05)$ within the ranges of 0.12 to $1.8 \mathrm{~cm}$.

\section{CONCLUSION}

The result of this research describe that there is an influence of oxygen supply through simple masks and the $30^{\circ}$ head elevation position to the changes in the awareness level of head injury patients at Dr Kariadi Hospital Semarang.

\section{ACKNOWLEDGEMENTS}

We wish to express our appreciation to all patients who participated in this study and to the dr. Kariadi General Hospital Semarang for valuable assistance during data collection.

\section{CONFLICTS OF INTEREST}

Neither of the authors have any conflicts of interests that would bias the findings presented here.

\section{REFERENCES}

1. Price, S. A, \& Wilson, L, M. 2012. Patofisiologi : Konsep Klinis Proses - Proses Penyakit, Edisi 6, Volume 2. Jakarta : EGC.

2. Soemitro D.W a , (2011). Sipnopsis Ilmu Bedah Saraf, Jakarta : CV Sagung Seto

3. Arifin, M. Z. 2013. Cedera Kepala : Teori dan Penanganan. Jakarta : Sagung Seto.

4. Haddad, S. H., \&Arabi, Y. M. 2012. Critical Care Management Of Severe Traumatic Brain Injury In Adults. Scand J Trauma Resuc Emergency Med 20 (12) : 1 - 15

5. Muttaqin, A. 2012. Pengantar Asuhan Keperawatan Klien Dengan Gangguan Sistem Persarafan. Jakarta : EGC.

6. Ricard, et.al.(2010) JournalassessingtheNeurological Status ofPatientswithHeadInjury.

7. Simon M, Andrew B, Mark CB. (2006). Intensive Care, 2nd ed, Elsievier Churcill Livingstone.

8. Badan Penelitian Dan Pengembangan Kesehatan Kementrian Kesehatan RI. (2013). Riset Kesehatan Dasar 2013. http://www.depkes.go.id/resources /download/general/Hasil\%20Riske sdas\%202013.pdf (Diakses 30 September 2018).

9. Potter dan Perry.(2005). Buku Ajar Fundamental Keperawatan.PenerbitBukuKedokteran.EGC. Jakarta.

10. Krisanty. Dkk. 2009. Asuhan Keperawatan Gawat Darurat, Jakarta : Trans Info Medika. 
11. Smeltzer, S. C. and Bare, B. G, 2006. Buku Ajar Keperawatan Medikal Bedah Brunner\&Suddarth, Edisi 8 Volume 2. Alih Bahasa H. Y. Kuncara, Monica Ester, Yasmin Asih, Jakarta : EGC.

12. Mansjoer, Arif. 2008. Kapita Selekta Kedokteran. Jakarta : EGC Buku Kedokteran.

13. Jackson, D. (2014). Keperawatan Medikal Bedah edisi 1. Yogyakarta, Rapha Pubishing.
14. Reeves, Charlene J. 2006. Buku Satu Keperawatan Medikal Bedah. Jakarta : Salemba Medika.

15. Carperito, L J. 2006. Diagnosa Keperawatan Aplikasi pada Praktek Klinik Edisi 6. Jakarta EGC.

16. Patricia A. Potter\&Pery, Anne G. (2011). Fundamental ofNursing : Fundamental Keperawatan Buku 3 Edisi 7. Jakarta : EGC. 